\title{
The Relationship Between Capital Structure and Firm Performance: The Case of Vietnam Material Enterprises
}

\author{
Thi Tho Do \\ University of Transport Technology
}

\begin{abstract}
The purpose of this study is to empirically investigate the relationship between capital structure and firm performance using a sample of Vietnam material enterprises. The annual financial statements of 20 material enterprises listed on the Vietnam Stock Exchange were used for this study which covers a period of twelve (12) years from 2008-2019. Multiple regression analysis was applied on performance indicators such as Return on Equity (ROE) as well as Short-term debt to Total assets (STD), Long term debt to Total assets (LTD) and Total debt to Equity (TDE) as capital structure variables. The results show that there is a negative relationship between LTD and ROE; while TDE is positively related with ROE. The study concludes that statistically, capital structure is a major determinant of firm performance. It recommends that managers of manufacturing companies should exercise caution while choosing the amount of debt to use in their capital structure.
\end{abstract}

Keywords: Capital Structure, Firm Performance, Vietnam Stock Exchange

DOI: $10.7176 /$ RJFA/11-12-16

Publication date:June 30th 2020

\section{Introduction}

Going beyond the boundaries of the theory of irrelevance, it was acknowledged that there is a link between the firm's capital structure and its value; subsequently, the literature in the field became less interested in the manner in which capital structure exerts influence over the firm's value, shifting its focus to the way in which changes in capital structure affect the governance structure and the global (including the financial) performance of the firm The theory of capital structure and its relationship with a firm's performance has been an issue of great concern in corporate finance and accounting literature since the seminal work of Modigliani and Miller (1958). They argue that under very restrictive assumptions of perfect capital market, investors' homogenous expectations, tax-free economy and no transaction costs, capital structure is irrelevant in determining firm value. Their subsequent preference of purely debt financing due to tax shield in 1963 was a contradiction to traditional approaches which suggests an optimal capital structure (Modigliani and Miller, 1963). In reality, establishing an optimal capital structure is a difficult task (Shoaib, 2011). He contends that a firm may require issuing a number of securities in a mixture of debt and equity to meet an exact combination that can maximize its value and having succeeded in doing so, the firm has achieved its optimal capital structure.

Capital structure is one of the most puzzling issues in corporate finance literature (Brounen \& Eichholtz, 2001). The concept is generally described as the combination of debt \& equity that make the total capital of firms. The proportion of debt to equity is a strategic choice of corporate managers. Capital structure decision is the vital one since the profitability of an enterprise is directly affected by such decision. Hence, proper care and attention need to be given while determining capital structure decision. In the statement of affairs of an enterprise, the overall position of the enterprise regarding all kinds of assets, liabilities are shown. Capital is a vital part of that statement. The term "capital structure" of an enterprise is actually a combination of equity shares, preference shares and long-term debts. A cautious attention has to be paid as far as the optimum capital structure is concerned. With unplanned capital structure, companies may fail to economize the use of their funds.

The objective of this study is to examine the impact capital structure has had on the performance of material enterprises in Vietnam. Specifically, it is aimed at: Examining the relationship between capital structure, and return on Equity. This study will be significant to managers in deciding the right combination of equity and debt to finance their operations and to maximize firm value at the same time contributing to the economic development of Vietnam.

The rest of this paper is as follows: the next section presents related literature and followed by methodology. The third section discuses research results. Conclusion discussed in the final section.

\section{Review of related literature}

Capital structure is referred to as the way in which the firm finances itself through debts, equity and securities. It is the composition of debt and equity that is required for a firm to finance its assets. The capital structure of a firm is very important since it is related to the ability of the firm to meet the needs of its stakeholders. The Board of Directors or the financial manager of a company should always endeavor to develop a capital structure that would lie beneficial to the equity shareholders in particular and to the other groups such as employees, customers, creditors and society in general 
Brander \& Lewis (1986) and Maksimovic (1988) provided the theoretical framework that links capital structure and market structure. Contrary to the profit maximization objective postulated in industrial organization literature, these theories, like the corporate finance theory, assume that the firm's objective is to maximize the wealth of shareholders and show that market structure affects capital structure by influencing the competitive behavior and strategies of firms. According to Brander \& Lewis (1986) firms in the oligopolistic market will follow the strategy of maximizing their output for improving profitability in favorable economic conditions. In unfavorable economic conditions, they would take a cut in production and reduce their profitability. Shareholders enjoy increased wealth in good periods, but they tend to ignore decline in profitability in bad times as unfavorable consequences are passed on to lenders because of shareholders' limited liability status. Thus the oligopoly firms, in contrast to the firms in the competitive markets, would employ higher levels of debt to produce more when opportunities to earn high profits arise. The implied prediction of the output maximization hypothesis is that capital structure and market structure have positive relationship.

Chiang et al. (2002) shows the inter-relationship between profitability, cost of capital and capital structure among property developers and contractors in Hong Kong. The data for this research paper was collected from Data stream, an electronic financial database. The analysis of this paper shows that gearing is generally higher among contractors than developers and capital gearing is positively related with asset but negatively with profit margins.

ElKelish (2007) also conducted a survey on the impact of financial structure on performance of businesses in the United Arab Emirates. He collected data from the financial statements of listed food companies from 1996 to 2000. Empirical results show that the debt to equity ratio had no impact on business performance.

The study of Arbabiyan and Safari (2009) on the impact of capital structure on profitability in 100 Iranian listed companies from 2001-2007 indicated a positive correlation between either the ratio of short-term debt or the debt ratio and ROE, while the ratio of long-term debt to total assets and ROE are negatively correlated.

Rehman et al. (2012) studied the relationship of leverage and profitability of textile companies in Pakistan. The authors randomly selected 17 companies in the textile industry and used the smallest mean method. Profitability was measured by ROE and leverage by the ratios of short-term debt to total assets, long-term debt to total assets and total liabilities to total assets. The results indicated a significantly positive correlation between the ratio of short-term debt to total assets and ROE, but the ratio of long-term debt to total assets and ROE were not significantly correlated.

Doan and Dinh (2014) analysed data of 235 companies listed on Ho Chi Minh City Stock Exchange in Vietnam from 2009 to 2013 and used the ratios of long-term debt to equity and total liabilities to equity to measure leverage. ROE and EPS (earnings per share) were indicators of profitability. The study pointed out a negative relationship between the selected leverage ratios and business performance.

Ramadan and Ramadan (2015) identified the effect of capital structure on the performance of 72 companies listed on the Amman Stock Exchange during the period between 2005 and 2013. This result is consistent with the Pecking-order theory when companies prefer equity.

Logavathani and Lingesiya (2018) investigated on the relationship between capital structure and performance of 10 commercial banks in Sri Lanka. ROA and ROE were two financial indicators used to measure profitability of banks. The ratios of short-term debt, long-term debt and total debt to total assets represent leverage. The results of FEM regression from ROA model and REM regression from ROE model highlighted that the ratio of total debt to total assets was closely and negatively related to ROA and ROE of commercial banks in Sri Lanka, and the ratios of short-term and long-term debt to total assets are not statistically significant related to ROA and ROE.

Capital structure literature has shown conflicting results among researchers. Some studies have shown that capital structure has significance impact on firm performance while others have shown no impact. With these mixed and conflicting results, the question for examining the relationship between capital structure and firm performance has remained a puzzle and empirical study continues.

\section{Research methodology}

Based on related reviews, the research model is constructed as follows (Figure 1):

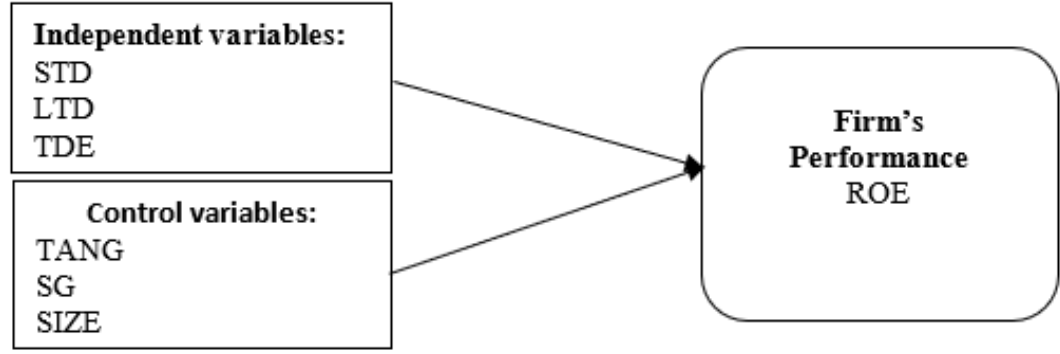

Figure 1. Research model 
Variable names and measurements in three models are explained in Table 1.

Table 1: Definition of model variables

\begin{tabular}{lll}
\hline Code & Variable name & Measurement \\
ROE & Return on Equity & Net income/ Stockholders' Equity \\
STD & Short term debt to total assets & Short term debt / Total assets \\
LTD & Long term debt to total assets & Long term debt / Total assets \\
TDE & Total debt to equity & Total debt /Equity \\
TANG & Tangibility & Fixed assets/ Total assets \\
GR & Sale Growth & (Current period net sales - previous period net sales)/ previous period \\
& & net sales \\
SIZE & Firm size & Firm size measured by log of total assets
\end{tabular}

Research data

The study relied on secondary data extracted from the audited financial statement of the selected companies. Data of these 20 material companies is collected from 2008 to 2019. Audit Financial Statements of these companies will be acquired from the Hanoi stock exchange Library, Ho Chi Minh stock exchange Library, and websites of these companies listed on the Vietnam stock market.

In the study, panel data regression models were employed to examine the determinants constructions companies' profitability in Vietnam. The panel data regression models were the Fixed effects model (FEM). Variables in the research model are shown in Table 1.

\section{Analysis findings and discussions}

Research results

Table 2. Descriptive statistic

\begin{tabular}{lccccccc}
\hline & ROE & STD & LTD & TDE & TANG & SG & SIZE \\
\hline Mean & 0.258132 & 0.034404 & 0.335952 & 0.834838 & 0.394940 & 0.367723 & 27.05128 \\
Median & 0.077715 & 0.027625 & 0.328091 & 0.909791 & 0.369227 & 0.042870 & 26.93015 \\
Maximum & 3.974429 & 0.207884 & 0.864593 & 1.000000 & 0.826910 & 45.33020 & 30.06816 \\
Minimum & -0.365356 & -0.003121 & -0.123408 & 0.257831 & 0.058876 & -1.602969 & 24.27831 \\
Std. Dev. & 0.508763 & 0.032497 & 0.193485 & 0.186323 & 0.172582 & 3.151350 & 1.509354 \\
Skewness & 3.900507 & 1.842793 & 0.460122 & -1.177980 & 0.436693 & 13.22277 & 0.257821 \\
Observations & 226 & 226 & 226 & 226 & 226 & 226 & 226 \\
\hline
\end{tabular}

Note. The descriptive statistic for the study presented in table1 was for constructions company for period of seven years covering 2008 to 2019. Statistical data (Table 2) show the mean value of ROE was 0.2581 of which the highest ROE was 3.9744 and the lowest ROE was -0.3653. In addition, the average value of short-term debt to total assets $(\mathrm{STD})$ is only $4 \%$ (Mean $(\mathrm{STD})=0.0344)$ while the ratio of long-term debt (LTD) is more than $33 \%$ $($ Mean $(\mathrm{STD})=0.3360)$. This implies that Vietnamese material companies mainly use long term debt to finance their operations due to the difficulty in their access to short-term credit from financial institutions.

Table 3. Correlation matrix

\begin{tabular}{llllllll}
\hline & ROE & STD & LTD & TDE & TANG & SG & SIZE \\
\hline ROE & 1.00 & 0.38 & -0.41 & 0.12 & -0.20 & 0.39 & 0.21 \\
STD & 0.38 & 1.00 & -0.31 & -0.03 & 0.28 & 0.32 & -0.16 \\
LTD & -0.41 & -0.31 & 1.00 & 0.32 & 0.08 & -0.15 & 0.06 \\
TDE & 0.12 & -0.03 & 0.32 & 1.00 & 0.03 & 0.06 & -0.39 \\
TANG & -0.20 & 0.28 & 0.08 & 0.03 & 1.00 & -0.03 & -0.35 \\
SG & 0.39 & 0.32 & -0.15 & 0.06 & -0.03 & 1.00 & 0.11 \\
SIZE & 0.21 & -0.16 & 0.06 & -0.39 & -0.35 & 0.11 & 1.00 \\
\hline
\end{tabular}

Note. The following Table 3 shows the correlation coefficients between variables. The purpose is to examine whether there is close correlation between independent variables and dependent variables to exclude variable that may lead to multi-collinearity. This is necessary step before running the regression. The results show that the correlation coefficient between any pair independent variables in the model is no less than 0.8 and therefore multicollinearity is unlikely to occur. 
Table 4. Regression Results

\begin{tabular}{lllll}
\hline \hline Variable & Coefficient & Std. Error & t-Statistic & Prob. \\
\hline \hline C & -2.438044 & 1.639055 & -1.487469 & 0.1386 \\
STD & 1.406274 & 1.190573 & 1.181175 & 0.2390 \\
LTD & -1.210989 & 0.263598 & -4.594068 & 0.0000 \\
TDE & 1.003577 & 0.185829 & 5.400529 & 0.0000 \\
TANG & -0.266558 & 0.180165 & -1.479519 & 0.1407 \\
SG & 0.022561 & 0.007970 & 2.830726 & 0.0051 \\
SIZE & 0.085533 & 0.058375 & 1.465229 & 0.1445 \\
\hline \hline & Effects Specification & & \\
& & & & 0.258132 \\
R-squared & 0.718337 & Mean dependent var & 0.508763 \\
Adjusted R-squared & 0.664687 & S.D. dependent var & 0.542286 \\
S.E. of regression & 0.294605 & Akaike info criterion & 1.102285 \\
Sum squared resid & 16.40376 & Schwarz criterion & 0.768279 \\
Log likelihood & -24.27832 & Hannan-Quinn criter. & 1.103364 \\
F-statistic & 13.38929 & Durbin-Watson stat & \\
Prob(F-statistic) & 0.000000 & & & \\
\hline \hline
\end{tabular}

Note. R-square value was found to be 0.7183 which indicates highly insignificant relationship between the variables, as $21.17 \%$ of the variation is attributable to factors outside this study. F- value indicates that the model used in the study is significant ( $\mathrm{prob}>\mathrm{F}=0.0000$ ). The result indicates a negative relationship between LTD and ROE while a positive relationship exists between TDE and ROA. This means an increase in LTD by one will reduce ROE by 1.21 respectively while a unit change in TDE will increase ROA by 1.00 . For material enterprises, I found no significant relationships between STD and performance.

Discussions

This paper examines the effects of capital structure on performance of Vietnamese listed material enterprises in the period of 2008 - 2019. In correlation with previous domestic and foreign studies, this study also contributes to a better explanation of the factors affecting firm performance.

The represented variable is ROE. According to empirical research results, 2 of 3 independent variables included in the study affect ROE: LTD and TDE. TDE has a positive impact on performance. Vice versa, LTD negatively impact on firm performance.

\section{Conclusion}

This study examines the impact of capital structure on firm performance. Base on the selected sample size and using capital structure indicators like STD, LTD and TDE as well as ROE as performance indicators, generally, there is a negative and positive relationship between capital structure and firm performance. The study concludes that statistically, capital structure represented by long- term debts to total assets (LTD) and total debt to equity (TDE) is a major determination of firm performance.

The study recommends that managers should be careful while using debt as a source of finance since a negative relationship exist between the capital structure and performance variables used in this work. They should try to finance their activities with retained earnings and use debt as a last option as supported by the pecking order theory

\section{References}

Arbabiyan, A. A., \& Safari, M. (2009). The effects of capital structure and profitability in the listed firms in Tehran Stock Exchange. Journal of Management Perspective, 33(12), 159-175.

Brander, J. A., \& Lewis, T. R. (1986). Oligopoly and financial structure: The limited liability effect. The American Economic Review, 956-970.

Brounen, D., \& Eichholtz, P. M. (2001). Capital structure theory: Evidence from European property companies' capital offerings. Real Estate Economics, 29(4), 615-632.

Chang, F. M., Wang, Y., Lee, N. R., \& La, D. T. (2014). Capital structure decisions and firm performance of Vietnamese soes. Asian Economic and Financial Review, 4(11), 1545-1563.

Doan, T.D., \& Dinh, T.H. (2014). Capital Structure and profitability of list companies in HoChiMinh City. Economics \& Development Journal. 2014 (Special issue in December), 30 - 37.

ElKelish, W.W. (2007) . Financial structure and firm value: empirical evidence from the United Arab Emirates. 
International Journal of Business Research, 7, 69-76.

International Journal of Economics and Finance, 7(6), 279-284.

Logavathani, S., \& Lingesiya, K. (2018). Capital structure and financial performance: A study on commercial banks in Sri Lanka. Asian Economic and Financial Review, Asian Economic and Social Society, 8(5), 586598

Maksimovic, V. (1988). Capital structure in repeated oligopolies. The RAND Journal of Economics, 389-407.

Modigliani, F., \& Miller, M. H. (1958). The Cost of Capital, Corporation Finance and The Theory of Investment, in "American Economic Review", n. 48.

Modigliani, F., \& Miller, M. H. (1963). Corporate income taxes and the cost of capital: a correction. The American economic review, 433-443.

Ramadan, Z.S., \& Ramadan, I.Z. (2015). Capital structure and firm's performance of Jordanian manufacturing sector.

Rehman, W., Fatima, G., \& Ahmad, M. (2012). Impact of debt structure on profitability in textile industry of Pakistan. Wali ur Rehman, Goher Fatima, Dr. Mehboob Ahmad, Impact Of Debt Structure On Profitability In Textile Industry Of Pakistan. International Journal of Economic Research, 3(2). 61-70.

Shoaib, A. (2011). Measuring performance through capital structure: Evidence from banking sector of Pakistan. African Journal of Business Management, 5(5), 1871-1879. 